\title{
EFFECT OF THIOUREA CONCENTRATION ON THE ELECTROCHEMICAL BEHAVIOR OF GOLD AND COPPER ELECTRODES IN PRESENCE AND ABSENCE OF Cu(II) IONS.
}

\author{
H. GÓMEZ, H. LIZAMA*, C. SUÁREZ, A. VALENZUELA
}

Instituto de Química, Facultad de Ciencias, Pontificia Universidad Católica de Valparaíso, Avenida Brasil 2950, Valparaíso, Chile

(Received: September 22, 2008 - Accepted: August 25, 2009)

\begin{abstract}
The effect of thiourea (TU) concentration on copper electrodeposition was studied employing cyclic voltammetry and electrochemical crystal quartz microbalance techniques. It was found that the polarization effects are related to the type of species generated in the electrode interface. Due to formation of formamidine disulfide (FDS) at concentrations greater than $10^{-4} \mathrm{~mol} \mathrm{dm}^{-3}$, the electrode surface is blocked, and copper electrodeposition shifts towards more negative potential values (polarizing effect). Lower concentrations favors the formation of $\mathrm{Cu}(\mathrm{I})-\mathrm{TU}$ contributing to the de-polarization of copper electrodeposition reaction.
\end{abstract}

Keywords: thiourea; electrodeposition; copper; crystal quartz microbalance; formamidine disulfide.

\section{INTRODUCTION}

Combination of glue, thiourea, and chloride are used as inhibitors in nearly all copper electrorefining tankhouses ${ }^{1-6}$. Although numerous investigations having been conducted, the mechanism of action of these inhibitors system has not been fully clarified. It is generally accepted that the additives produce an additional local overpotential at the more active cathode sites, favoring the formation of a low roughness homogenous surface ${ }^{7}$. In the particular case of thiourea (TU), its role in copper electrodeposition is mainly related to the formation and distribution of grain size ${ }^{8}$ but the associated chemical and electrochemical mechanisms of these processes are still not completely understood. Most of the papers related to TU are devoted to the study of anodic processes, such as the protection against corrosion of copper-iron alloys structures ${ }^{9}$, lixiviation ${ }^{10}$, gold cementation ${ }^{11}$, etc.

Some studies focused in the interaction of TU with different electrodes surfaces $(\mathrm{Au}, \mathrm{Pt}, \mathrm{Ag}, \mathrm{Cu})$, provide evidences that support the participation of the TU/FDS redox couple, according to the following irreversible reaction $^{12-14}$

$$
\text { ,FDS }+2 \mathrm{H}++2 \mathrm{e} \rightarrow 2 \mathrm{TU}
$$

$\left[\mathrm{Cu}(\mathrm{TU})_{\mathrm{x}+\mathrm{y}}\right]^{\mathrm{x}}$ complexes on copper electrodes polarized at positive potentials has been also reported ${ }^{12}$. The formation of this type of complexes is restricted to metals less noble than platinum, including the gold electrode ${ }^{9-15}$. Besides, in the potential domain of cathodic processes the electroreduction of metallic complexes as well as the FDS adsorption are involved ${ }^{16}$. On platinum electrodes there is no evidence of complexes formation and only the partial or total oxidation of FDS has been reported ${ }^{1}$.

Although there are an important amount of papers dealing with the electrochemical behavior of $\mathrm{TU}$ on different electrodes ${ }^{17-20}$, information regarding the role that this additive plays in the copper electrodeposition process is scarce. Aspects such as the interaction of TU with the electrode and electrolyte, chemical and electrochemical formation of FDS in strongly acid solutions, $\mathrm{Cu}-\mathrm{TU}$ complexes formation, and electrode surface inhibition are important points that need to be systematically addressed. In current paper, we have studied the electrochemical behavior of TU on gold and copper electrodes in an acid electrolyte in presence and absence of $\mathrm{Cu}(\mathrm{II})$ ions. Cyclic voltammograms and nanogravimmetric measurements recorded on both electrodes at variables TU concentrations give useful information to get a deeper knowledge of the $\mathrm{Cu} / \mathrm{TU} /$ acid solution interface, helping to interpret the complexity of reactions involved in these electrochemical systems.

\section{EXPERIMENTAL}

Cyclic voltammetry and nanogravimmetric measurements were carried out in a conventional three-electrode cell. Table 1 summarizes the characteristics of the working electrodes used.
Table1. Working electrodes employed.

\begin{tabular}{|l|c|}
\hline \multicolumn{1}{|c|}{ Electrode } & Geometric area $/ \mathrm{cm}^{2}$ \\
\hline $\mathrm{Cu}$ & 0.071 \\
\hline $\mathrm{Au}$ & 0.023 \\
\hline $\begin{array}{l}\mathrm{Au} \text { (Electrochemical Cristal Quartz } \\
\mathrm{Microbalance} \text { ECQM) }\end{array}$ & 1.370 \\
\hline $\mathrm{Au} / \mathrm{Cu}_{\text {electrodeposited (ECQM) }}$ & 1.370 \\
\hline
\end{tabular}

A saturated mercurious sulfate electrode was used as reference (-0.690 vs NHE), all potentials in the text are referred to this electrode. For voltammetric experiments the counter-electrode was a platinum wire with a geometric area of $3 \mathrm{~cm}^{2}$, whereas for measurements with EQCM a $1.37 \mathrm{~cm}^{2}$ titanium platinized wire was employed. Before each run of $\mathrm{CV}$ and EQCM experiments, the electrolytic solutions were de-aerated for 45 minutes with high purity argon, a flux of this gas was maintained during the measurements. A computer controlled potentiostat (Autolab, Model PGSTAT30) and a EQCM (Mastex, Model QCM) were used for cyclic voltammetry and nanogravimmetric experiments, respectively. The following solutions were prepared with analytical grade reagents (Merck P.A.) in de-ionized water: $0.30 \mathrm{~mol} \mathrm{l}^{-1} \mathrm{H}_{2} \mathrm{SO}_{4}$ (soln. A ), $0.8 \mathrm{~mol} \mathrm{l}^{-1} \mathrm{H}_{2} \mathrm{SO}_{4}$ (soln. B), $1.8 \mathrm{~mol} \mathrm{l}^{-1} \mathrm{H}_{2} \mathrm{SO}_{4}$ (soln. C), $0.3 \mathrm{~mol} \mathrm{l}^{-1}$ $\mathrm{H}_{2} \mathrm{SO}_{4}, 50 \mathrm{mmol} \mathrm{l}^{-1} \mathrm{CuSO}_{4}$ (soln.D).

\section{RESULTS AND DISCUSSION}

1. Cyclic Voltammetry and nanogravimetric studies at gold substrates.

The voltammetric response of TU was first investigated employing a gold working electrode in sulfuric acid solution, in absence of $\mathrm{Cu}$ (II) ions. In absence of $\mathrm{TU}$, the voltammogram of the $\mathrm{Au} / \mathrm{H}_{2} \mathrm{SO}_{4}$ interface recorded after 15 minutes of potential scans presents the typical anodic and cathodic current contributions related to the electroformation and electroreduction of gold oxide species, (Fig.1). 


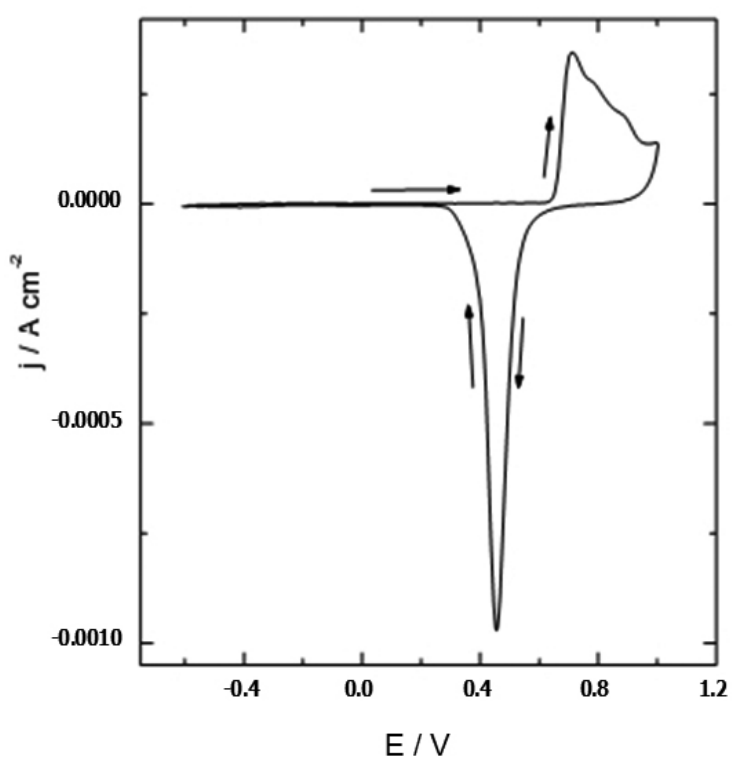

Fig. 1. Cyclic voltammogram of the $\mathrm{Au} / \mathrm{H}_{2} \mathrm{SO}_{4} 0.3 \mathrm{~mol} \mathrm{~L}^{-1}$ interface after the $\mathrm{n}^{\text {th }}$ cycle. Scan rate : $0.100 \mathrm{~V} \mathrm{~s}^{-1}$

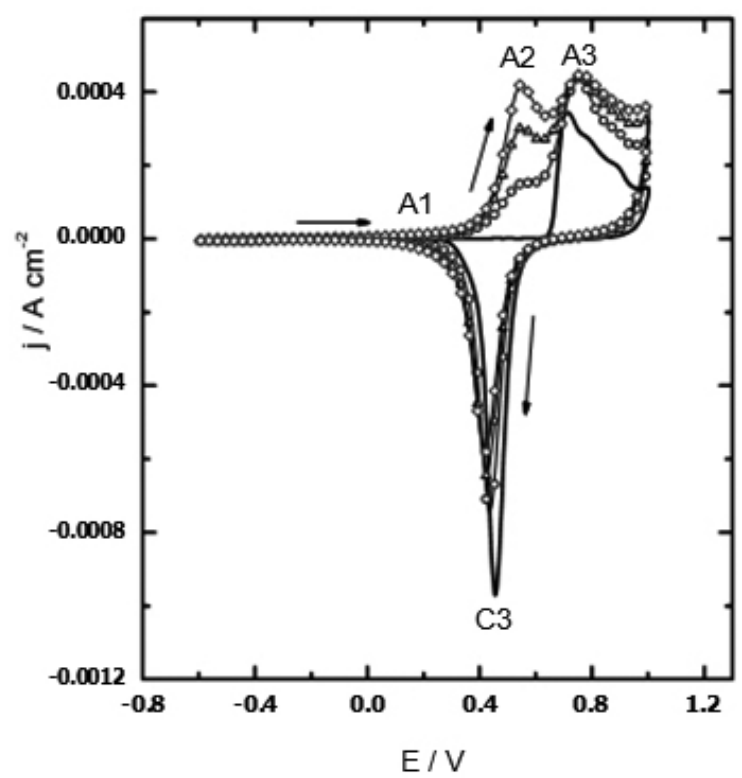

Fig. 2. Effect of Tu on cyclic voltammograms at the $\mathrm{Au} / \mathrm{H}_{2} \mathrm{SO}_{4} 0.3 \mathrm{~mol} \mathrm{~L}^{-1}$ interface. Scan rate $0.100 \mathrm{~V} \mathrm{~s}^{-1} ;(--)$ without TU ; (-0-) 4.9.10-5 $\mathrm{mol} \mathrm{L}^{-1} \mathrm{TU} ;\left(-\Delta_{-}\right)$ $\left.8.6 \cdot 10^{-5} \mathrm{~mol} \mathrm{~L}^{-1} \mathrm{TU} ;(-\diamond-)\right) 1.0 \cdot 10^{-4} \mathrm{~mol} \mathrm{~L}^{-1} \mathrm{TU}$.

The addition of variable amounts of TU produces new anodic current contributions in the voltammogram (Fig. 2): a current plateau between -0.65 and $0.30 \mathrm{~V}(\mathrm{~A} 1)$, not significatively affected by TU concentration; A2 peak with a maximum at $0.54 \mathrm{~V}$, strongly dependent on TU concentration and, A3 peak in the potential region of gold oxides formation. As TU concentration increases, the latter contribution undergoes a small current increase, probably due to the presence of adsorbed TU species which can block electrode surface sites. The latter assumption is confirmed during the cathodic scan because the charge of current peak $\mathrm{C} 3$, related to the electroreduction of gold oxides formed in the anodic scan, progressively diminishes as a consequence of a TU blocking effect.
The increasing in TU concentration (in the range $4.7 \cdot 10^{-4}$ to $1.4 \cdot 10^{-3} \mathrm{~mol} \mathrm{~L}^{-1}$ ) reveals an increase in the current associated to process $\mathrm{A} 1$ and the apparitionof a new cathodic peak (C1) at $-0.41 \mathrm{~V}$ (Fig. 3). Considering the irreversible character of the electrochemical processes involved in these conjugated peaks, they are probably related to the TU/FDS redox couple. On the other hand, the developing and shifting of peak A2 towards positive potential (overlapped with peak A3), would be related to the formation of $\mathrm{Au}(\mathrm{I})-\mathrm{TU}$ complexes [21 - 23].

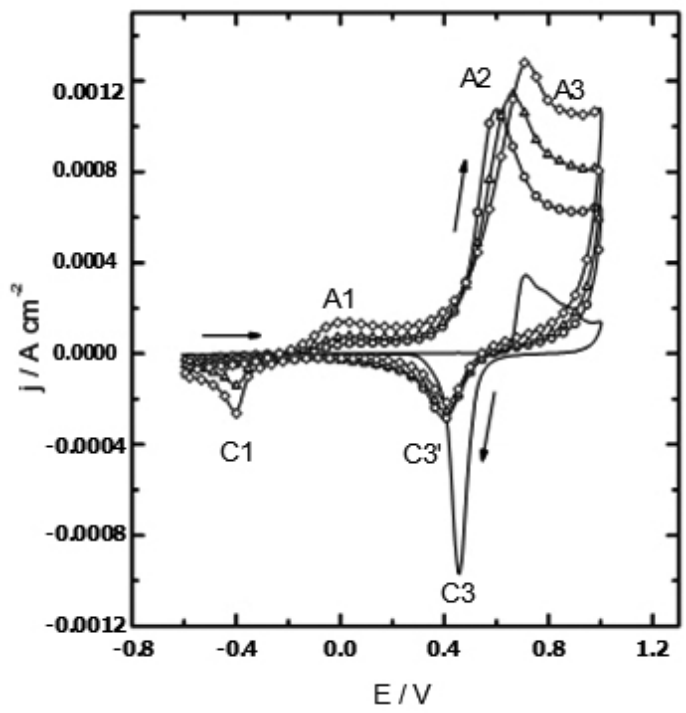

Fig. 3. Voltammogram of the $\mathrm{Au} / 0.3 \mathrm{~mol} \mathrm{~L}^{-1} \mathrm{H}_{2} \mathrm{SO}_{4}$ interface. Scan rate $0.100 \mathrm{~V} \mathrm{~s}^{-1}$. (--) without TU ; (-0-) $4.7 \cdot 10^{-4} \mathrm{~mol} \mathrm{~L}^{-1} \mathrm{TU} ;(-\Delta-) 8.5 \cdot 10^{-4} \mathrm{~mol} \mathrm{~L}^{-1} \mathrm{TU}$ $;(-\diamond-) 1.4 \cdot 10^{-3} \mathrm{~mol} \mathrm{~L}^{-1} \mathrm{TU}$

In order to establish the conjugation of the different redox couples involved, the anodic switching potential, $\mathrm{E}_{\lambda}$, was systematically moved from $1.0 \mathrm{~V}$ towards negative values (Fig.4). Under these conditions, the conjugation between the electroformation and electroreduction of gold oxides (peaks A3 and $\mathrm{C} 3$, respectively) appears clearly resolved. Moving $\mathrm{E}$ between 0.70 and 0.30 $\mathrm{V}$ produces peak $\mathrm{C} 2$ (conjugated with the $\mathrm{A} 2$ process), which is assigned to the reduction of $\mathrm{Au}(\mathrm{I})$-TU complexes [18]. Similarly, between 0.30 and -0.14 $\mathrm{V}$ the conjugation of the $\mathrm{A} 1 / \mathrm{C} 1$ peaks, associated to the irreversible TU/FDS couple is also confirmed [18, $21-23]$.

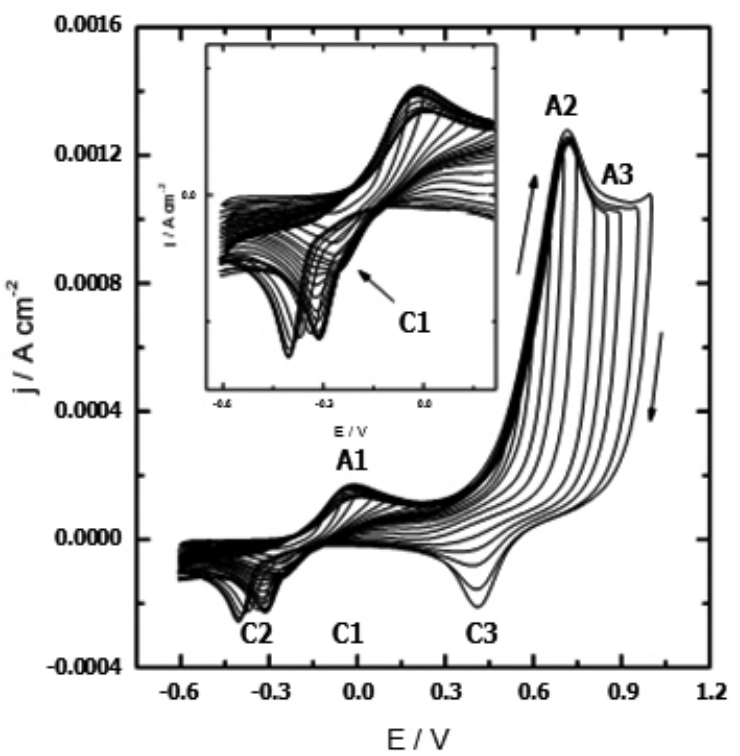

Fig.4. Voltammogram of the $\mathrm{Au} / 0.3 \mathrm{~mol} \mathrm{~L}^{-1} \mathrm{H}_{2} \mathrm{SO}_{4}$ interface. Scan rate $0.100 \mathrm{~V} \mathrm{~s}^{-1}$. TU $1.4 \cdot 10^{-3} \mathrm{~mol} \mathrm{~L}^{-1}$ 
In order to get a deeper insight on the electrochemical system under study, a set of voltammetric/nanogravimetric coupled experiments were conducted,. Figure 5 presents the $\mathrm{j} / \mathrm{E}$ and $\Delta \mathrm{m} / \mathrm{E}$ curves corresponding to the $\mathrm{Au}_{\mathrm{FQCM}}$ / solution A interface, in presence of $1.4 \cdot 10^{-3} \mathrm{~mol} \cdot \mathrm{L}^{-1} \mathrm{TU}$. It is observed that in the -0.09 y $0.25 \mathrm{~V}$ potential interval, the electrooxidation of TU to FDS is produced together with a mass loss attributed to the formation and liberation of hydrogen ions according to reaction:

$$
2 \mathrm{TU}_{\text {ads }}+\mathrm{FDS}_{\mathrm{ads}}+2 \mathrm{H}^{+}+2+\overline{\mathrm{e}}
$$

This process probable occurs simultaneously with the loss of either water molecules or sulfate ions adsorbed at the interface, which are removed due to the FDS formation. In the 0.25 to $0.5 \mathrm{~V}$ potential interval there is a new mass loss, attributed in this case to the gold electrodissolution and further formation of a $\mathrm{Au}-\mathrm{Tu}$ complex produced through reaction,

$$
2 \mathrm{TU}+\mathrm{Au} \rightarrow \mathrm{Au}(\mathrm{TU}+) 2+\mathrm{e}
$$

This reaction is followed by the formation of gold oxide with the corresponding increase of mass. As in the 1.05 and $0.75 \mathrm{~V}$ potential interval the formation of gold oxides is favored, the mass still increases during the cathodic sweep Between 0.75 and $-0.25 \mathrm{~V}$ there is an important mass decreasing, associated to the oxides gold reduction. This is confirmed by the reduction peak appearing in the voltammogram of Figure 5 in the same potential interval. Finally, from $0.25 \mathrm{~V}$ backwards, there is again a mass increase, now related to the reduction of FDS and Au-TU complex to TU.

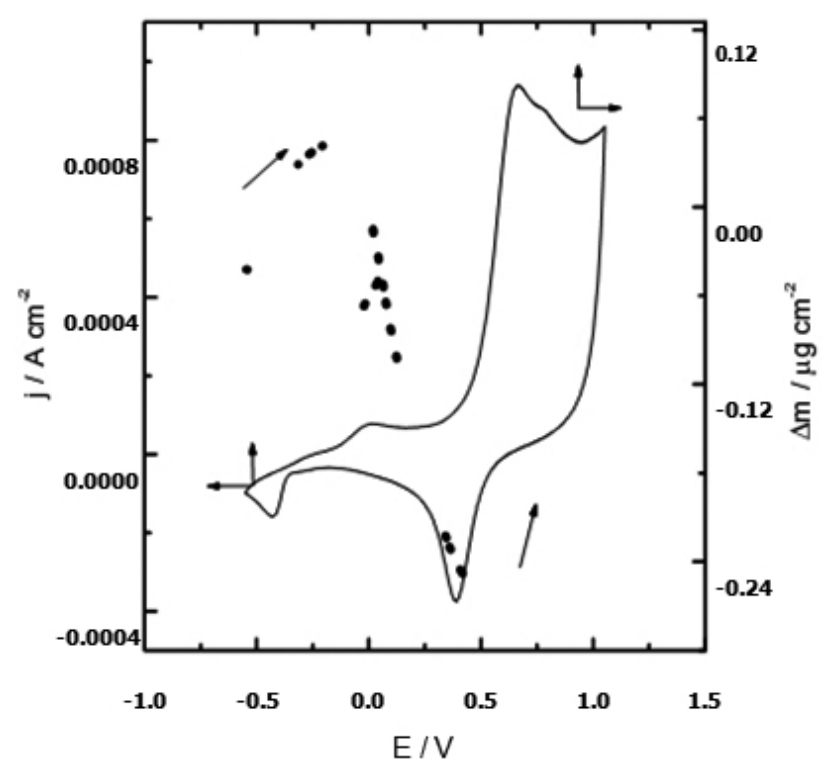

Fig. 5. $\mathrm{Au}_{\mathrm{EQCM}} / 0.3 \mathrm{~mol} \mathrm{~L}^{-1} \mathrm{H}_{2} \mathrm{SO}_{4}, 1.4 \cdot 10^{-3} \mathrm{~mol} \mathrm{~L}^{-1} \mathrm{TU}$ interface. Scan rate 0.1 $\mathrm{V} \mathrm{s}^{-1}$. (---) j/E profile (-----) $\Delta \mathrm{m} / \mathrm{E}$ profile

\section{2. $\mathrm{Cu} / \mathrm{H}_{2} \mathrm{SO}_{4} / \mathrm{TU}$ interface.}

Figure 6a presents the voltammetric behavior of $\mathrm{Cu} /$ solution $\mathrm{A}$ interface recorded between -1.24 and $-0.34 \mathrm{~V}$, starting in the anodic direction from the open circuit potential(ca $-0.39 \mathrm{~V})$. The typical behavior of a copper electrode is observed in absence of TU. An important diminution of the charge associated to copper redox process is observed when TU is progressively added to the electrolytic solution (see inset of figure 6a). This effect can be again explained assuming the blocking of copper sites either by TU, FDS or by both species. a)

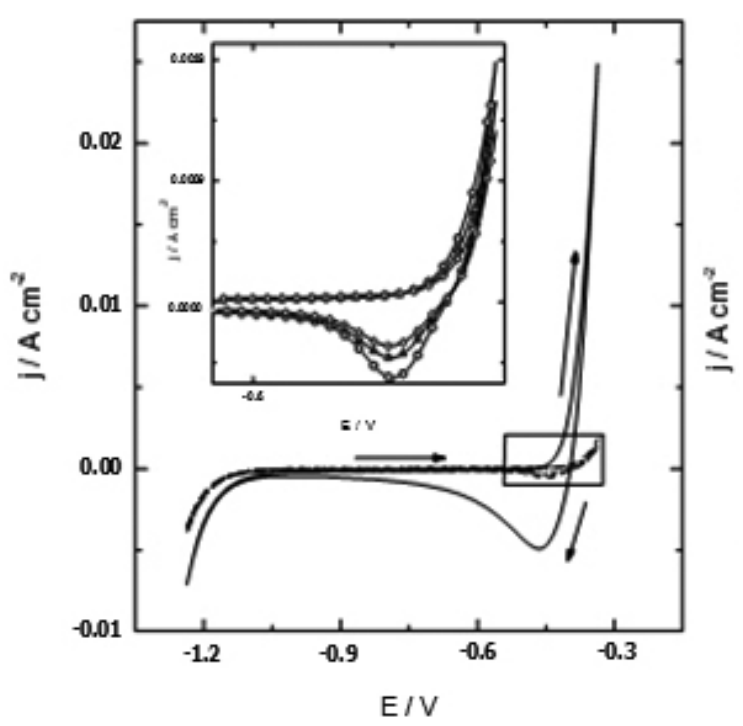

b)

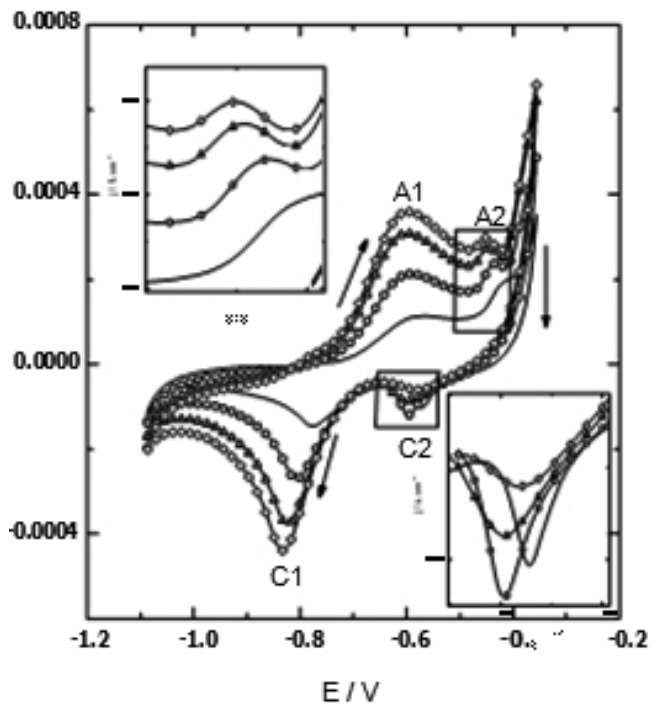

Fig. 6. Voltammogram of the $\mathrm{Cu} / 0.3 \mathrm{~mol} \mathrm{~L}^{-1} \mathrm{H}_{2} \mathrm{SO}_{4}$ interface. Scan rate $0.100 \mathrm{~V} \mathrm{~s}^{-1}$. a) (--) without TU ; (-0-) $1 \cdot 10^{-5} \mathrm{~mol} \mathrm{~L}^{-1} \mathrm{TU}^{4}(-\Delta-) 2 \cdot 10^{-5} \mathrm{~mol} \mathrm{~L}^{-1}$ TU; (- $\diamond-) 3 \cdot 10^{-5} \mathrm{~mol} \mathrm{~L}^{-1} \mathrm{TU}$. b) (--) $5.7 \cdot 10^{-4} \mathrm{~mol} \mathrm{~L}^{-1} \mathrm{TU}$; (-0-) $1.1 \cdot 10^{-3} \mathrm{~mol} \mathrm{~L}^{-1}$ TU; $(-\Delta-) 1.7 \cdot 10^{-3} \mathrm{~mol} \mathrm{~L}^{-1} \mathrm{TU} ;(-\diamond-) 2 \cdot 10^{-3} \mathrm{~mol} \mathrm{~L}^{-1} \mathrm{TU}$.

Scanning the potential from the open circuitpotential and $\mathrm{E}_{\lambda \mathrm{A}}=-0.36 \mathrm{~V}$ in the anodic direction, theincrease of TU concentration from $5.7 \cdot 10^{-4}$ to $2 \cdot 10^{-3} \mathrm{~mol} \cdot \mathrm{L}^{-1}$ (see inset offigure 6 b) produces peaks A1 and A2. The former has been attributed to the electroadsorption of TU to FDS [3], whereas the latter is associated to the electroformation of $\mathrm{Cu}(\mathrm{I})-\mathrm{TU}$ complexes, previously reported in the literature [3]. The corresponding conjugated peaks $\mathrm{C} 1$ and $\mathrm{C} 2$ are observed during the cathodic scan. The correlation of these processes at constant TU concentration was followed moving progressively $\mathrm{E}_{2}$ towards cathodic values (Figure 7) and recording the $\mathrm{j} / \mathrm{E}$ and $\Delta \mathrm{m} / \mathrm{E}$ ) curves obtained with the gold electrode of the EQCM, covered with a copper layer. 


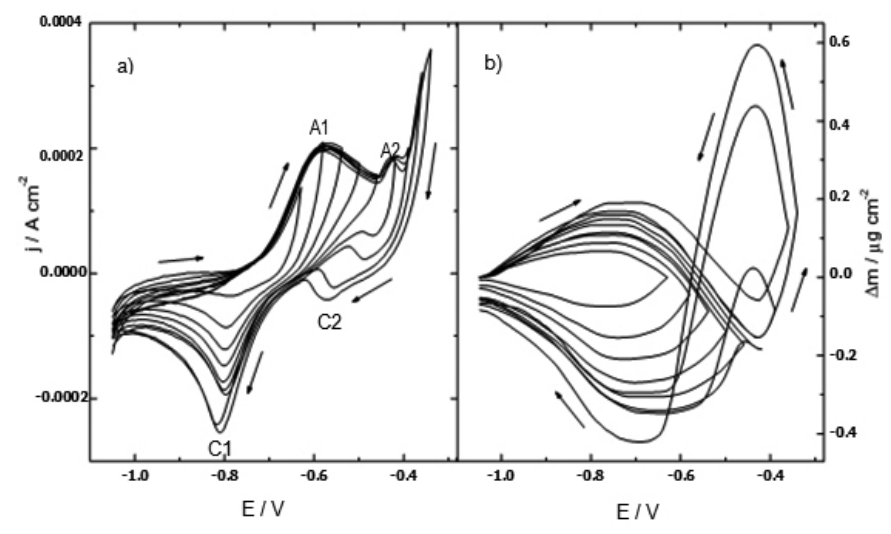

Fig 7. $\mathrm{Au}_{\mathrm{EOCM}} / \mathrm{Cu} / 0.3 \mathrm{~mol} \mathrm{~L}^{-1} \mathrm{H}_{2} \mathrm{SO}_{4}, 2 \cdot 10^{-3} \mathrm{~mol} \mathrm{~L}^{-1} \mathrm{TU}$ interface. Scan rate $0.1 \mathrm{~V} \mathrm{~s}^{-1}$. a) $\mathrm{j} / \mathrm{E}$ profile. b) $\Delta \mathrm{m} / \mathrm{E}$ profile.

Figure 7a shows the relationship between $\mathrm{A} 2 / \mathrm{C} 2$ and $\mathrm{A} 1 / \mathrm{C} 1$ conjugated processes: the former are related to the participation of the $\mathrm{Cu}-\mathrm{TU}(\mathrm{I})$ complex, represented by the redox couple, and, the latter is associated to the TU/FDS couple according to reaction:

$$
\begin{array}{r}
\mathrm{CuTU}++\mathrm{e} \rightarrow \mathrm{Cu}+\mathrm{TU} \\
\mathrm{FDS}+2 \mathrm{H}++2 \mathrm{e} \rightarrow 2 \mathrm{TU}
\end{array}
$$

So far, it is important to highlight the differences observed for copper and gold electrodes regarding the potential interval where the complexes are reduced at both interfaces. On the copper electrode, the process takes place at potentials more positives than the electroreduction of FDS to TU. On the contrary, on the gold electrode, the TU complexes are reduced at potential negatives to the FDS/TU couple, indicating a greater electrochemical reversibility of the copper complexes. This behavior suggests the possibility that TU may act as a de-polarizing agent for copper electroreduction reaction.

Asitwasfoundforthegoldelectrode, inthepotentialregionwheretheformationof CU(I)-TU complexes prevails, the general tendency of the $\Delta \mathrm{m} / \mathrm{E}$ curves(figure $7 \mathrm{~b}$ ) associated to the TU-FDS couple is towards a mass decreasing. When the potential excursion is extended towards the $\mathrm{E}_{\text {a }}$ anodic switching potential limit, a mass increase due to formation of copper oxides is produced. Due to their thermodynamic stability, this mass increasing is observed until a potential of ca $-0.60 \mathrm{~V}$ is reached. Afterwards, a loss of mass due to the reduction of both, copper oxides and $\mathrm{Cu}(\mathrm{I})-\mathrm{TU}$ complexes adsorbed at the electrode surface, is observed at more cathodic potentials. As in the case for gold electrodes, after these processes the $\Delta \mathrm{m} / \mathrm{E}$ profiles show a mass increase due to the electrochemical reduction of FDS to TU.

\section{3. $\mathrm{Au} / \mathrm{CuSO}_{4} / \mathrm{H}_{2} \mathrm{SO}_{4} / \mathrm{TU}$ interface}

The presence of $\mathrm{Cu}(\mathrm{II})$ ions introduces important modifications in the electrochemical behavior of the electrodes under study. Actually, in aqueous solutions they can react with $\mathrm{TU}$ giving a $\mathrm{Cu}(\mathrm{I})-\mathrm{TU}$ complex and FDS, the same species that are electrochemically formed at the working electrodes as just described in preceding sections.

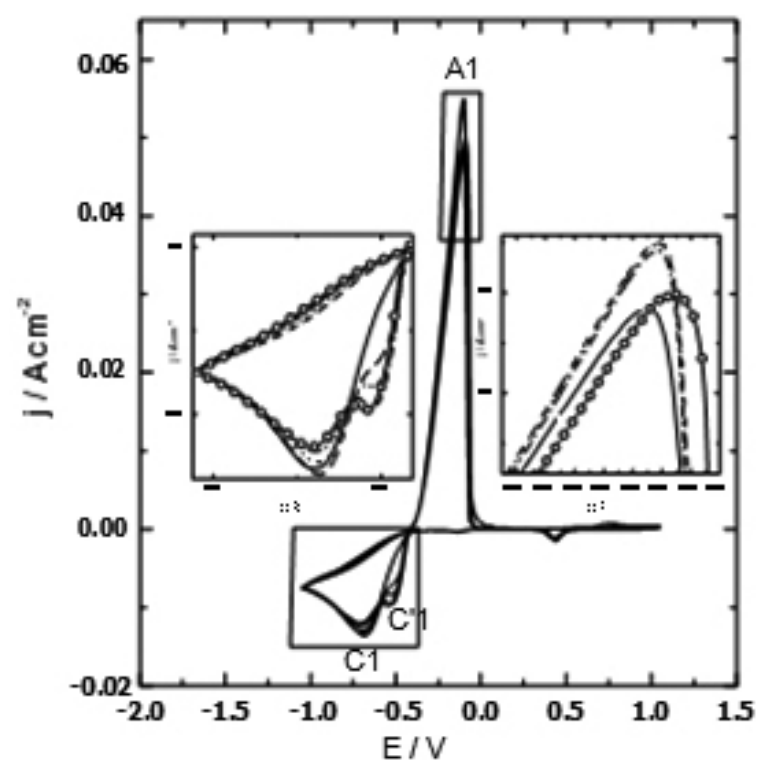

Fig.8. Voltammogram of the $\mathrm{Au} / 0.3 \mathrm{~mol} \mathrm{~L}^{-1} \mathrm{H}_{2} \mathrm{SO}_{4}, 50 \mathrm{mmol} \mathrm{L}^{-1} \mathrm{CuSO}_{4}$ interface. Scan rate $0.100 \mathrm{~V} \mathrm{~s}^{-1}$. ) $\mathrm{CuSO}_{4}$ without $\mathrm{TU} ;(--) 1 \cdot 10^{-5} \mathrm{~mol} \mathrm{~L}^{-1} \mathrm{TU}^{4}$ (0000) $\left.2 \cdot 10^{-5} \mathrm{~mol} \mathrm{~L}{ }^{-1} \mathrm{TU} ;(--0-) 4 \cdot 10^{-5} \mathrm{~mol} \mathrm{~L}{ }^{-1} \mathrm{TU} ;(-\diamond-)\right) 7.7 \cdot 10^{-5} \mathrm{~mol} \mathrm{~L}^{-1} \mathrm{TU}$.

Besides the characteristic behavior of the gold substrate in absence of TU, the voltammogram recorded in theanodic direction, starting from the open circuit potential, presents current peak A1, with a maximum at $-0.10 \mathrm{~V}$, which is related to the stripping of the copper deposited after successive potential sweeps (Figure 8). The electroreduction of $\mathrm{Cu}$ (II) to $\mathrm{Cu}(0)$ starts at $-0.42 \mathrm{~V}$, with a maximum at $-0.70 \mathrm{~V}$. Adding increasingly amounts of TU produces an additional cathodic peak at $-0.50 \mathrm{~V}$ (C'1), attributed to the reduction of $\mathrm{CuTU}^{+}$formed from reaction

$$
2 \mathrm{Cu}^{2+}++4 \mathrm{TU} \rightarrow 2 \mathrm{CuTU}^{+}++\mathrm{FDS}+2 \mathrm{H}^{+}
$$

According to previous voltammetric description, the following tendencies are observed: i) for TU concentrations ranging from $1 \cdot 10^{-}$ $5 \mathrm{~mol} \cdot \mathrm{L}^{-1}$ to around $4 \cdot 10^{-5} \mathrm{~mol} \cdot \mathrm{L}^{-1}$ the current of peak $\mathrm{C}^{\prime} 1$ increases and remains constant at higher concentrations. In turn, in agreement with the formation of a complex, the current of peak $\mathrm{C} 1$ diminishes as the TU concentration increases; ii) the depolarization of the copper electrodeposition process takes place in the same concentration range, the inset in figure 8 accounting for this behavior. Depolarization is produced by the increase in the stripping (peak A1) of the electrodeposited copper that was generated with the participation of the $\mathrm{Cu}-\mathrm{TU}$ complex (peak C'1). In fact, as the $\mathrm{Cu}-\mathrm{TU}$ complex requires one equivalent of charge in order to achieve copper electrodeposition, additionally contributes to increase the overall electrodeposition rate.

Regarding the electrode polarization, the increase of TU concentration over $7.9 \cdot 10^{-5} \mathrm{~mol} \cdot \mathrm{L}^{-1}$ produces the inverse behavior observed in the voltammogramas of Figure 8. This is appreciated in the cathodic hemicycle (Figure 9) where a charge decrease in the $\mathrm{Cu}(\mathrm{I}) / \mathrm{Cu}$ (close to $0.5 \mathrm{~V}$ ), and in the $\mathrm{Cu}(\mathrm{II}) / \mathrm{Cu}$ couples is observed. This means that the blocking of the electrode surface takes place in an extension that not only modifies the charge of the processes involved, but also shifts their respective potentials towards more negative values. Under these circumstances, the electrode surface is completely modified by the massive adsorption of FDS according to:

$$
\begin{aligned}
& \mathrm{Cu}+\mathrm{FDSCu}-\mathrm{FDS}_{\text {ads }} \\
& \mathrm{Cu}-\mathrm{FDS}_{\mathrm{ads}}+\mathrm{CuTU}^{+} \text {) } \\
& \mathrm{Cu}-\mathrm{FDS}_{\mathrm{ads}}+\mathrm{Cu}^{2+}
\end{aligned}
$$

The progressive decrease of the peak associated to the oxidation of $\mathrm{Cu}$ electrogenerated in the successive scans confirms this voltammetric behavior. 


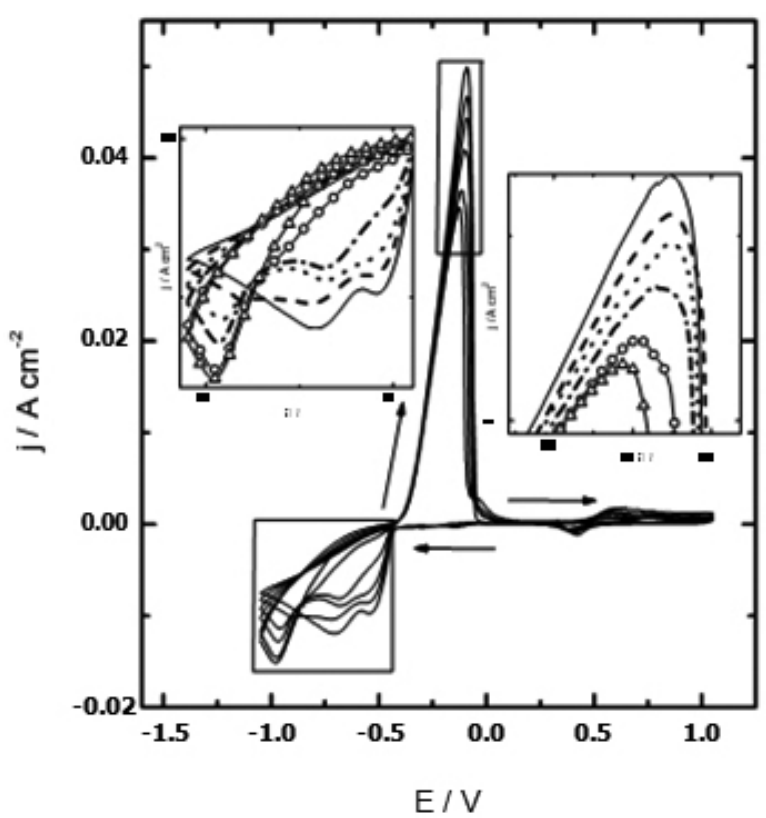

Fig. 9. Voltammogram of the $\mathrm{Au} / 0.3 \mathrm{~mol} \mathrm{~L}^{-1} \mathrm{H}_{2} \mathrm{SO}_{4}, 50 \mathrm{mmol} \mathrm{L}-1 \mathrm{CuSO}_{4}$ interface. Scan rate $0.100 \mathrm{~V} \mathrm{~s}^{-1}$. (-) $7.7 \cdot 10^{-5} \mathrm{~mol} \mathrm{~L}^{-1} \mathrm{TU}$; (--) $1.7 \cdot 10^{-4} \mathrm{~mol} \mathrm{~L}^{-1} \mathrm{TU}$; (-- ) $2.7 \cdot 10^{-4} \mathrm{~mol} \mathrm{~L}^{-1} \mathrm{TU}$; (--) $3.6 \cdot 10^{-4} \mathrm{~mol} \mathrm{~L}^{-1} \mathrm{TU}$; (--) $5.6 \cdot 10^{-4} \mathrm{~mol} \mathrm{~L}^{-1} \mathrm{TU}$; (--) $7.5 \cdot 10^{-4} \mathrm{~mol} \mathrm{~L}^{-1} \mathrm{TU}$.

\section{EQCM Au/Cu $/ \mathrm{Cu}_{\text {electrodeposited }} / \mathrm{CuSO}_{4} / \mathrm{H}_{2} \mathrm{SO}_{4} / \mathrm{TU}$ interface}

In order to establish the charge/mass relationships of the electrochemical system under study, the $\mathrm{j} / \mathrm{E}$ and $\Delta \mathrm{m} / \mathrm{E}$ response were evaluated (Figure 10).

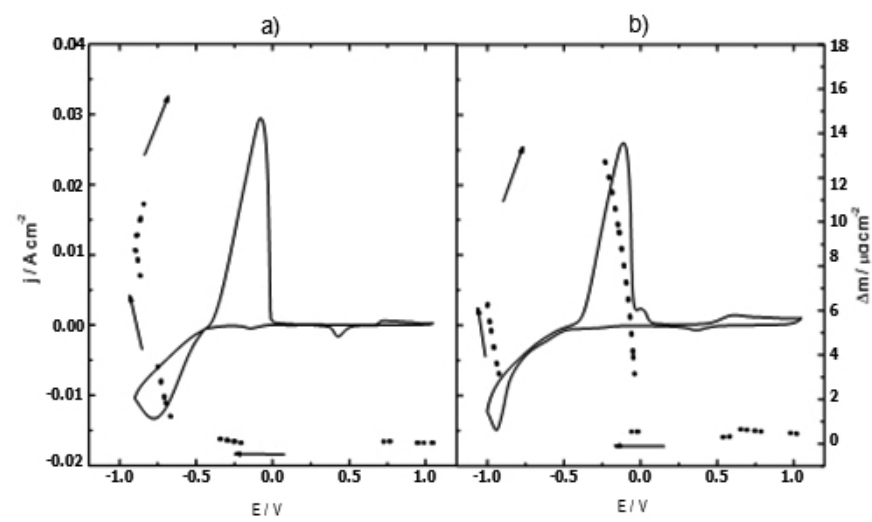

Fig.10. $\mathrm{Au}_{\mathrm{FOCM}} / \mathrm{Cu} / 0.3 \mathrm{~mol} \mathrm{~L}^{-1} \mathrm{H}_{2} \mathrm{SO}_{4}, 50 \mathrm{mmol} \mathrm{L}^{-1} \mathrm{CuSO}_{4}$ interface. Scan rate $0.1 \mathrm{~V} \mathrm{~s}^{-1}$. a) without TU. b) $1.4 \cdot 10^{-3} \mathrm{~mol} \mathrm{~L}^{-1}$ TU. (-) j/E profile; (---) $\Delta \mathrm{m} / \mathrm{E}$ profile.

Figure 10a shows the typical response of the gold electrode in a copper acid solution ( i.e. mass increase in the cathodic scan and mass loss during copper stripping). In the presence of TU (figure 10b), the blocking of the electrode surface, is evidenced. Although in the 0.5 and $-1.0 \mathrm{~V}$ interval appear two mass changes attributed to $\mathrm{Cu}(\mathrm{I})-\mathrm{TU}$ $\rightarrow \mathrm{Cu}(0)$ and $\mathrm{Cu}(\mathrm{II}) \rightarrow \mathrm{Cu}(0)$ reductions, this behavior reveals that copper electrodeposition is still the most important process involved. To confirm these assumptions, relationships for the variation of charge and mass over time were determined through the $\mathrm{Q} / \mathrm{t}$ and $\Delta \mathrm{m} / \mathrm{t}$ transients for further determining $\mathrm{Q} /$ $\Delta \mathrm{m}$, and the number of electrons involved in the copper electrodeposition process. a)

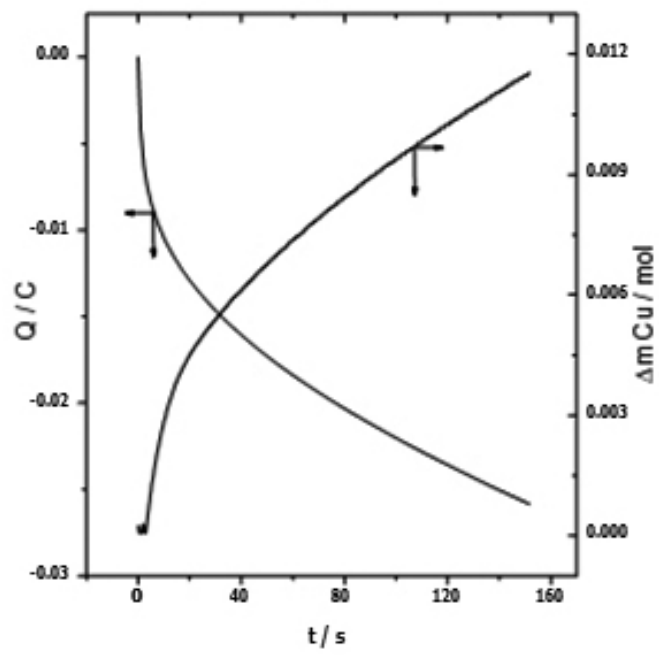

b)

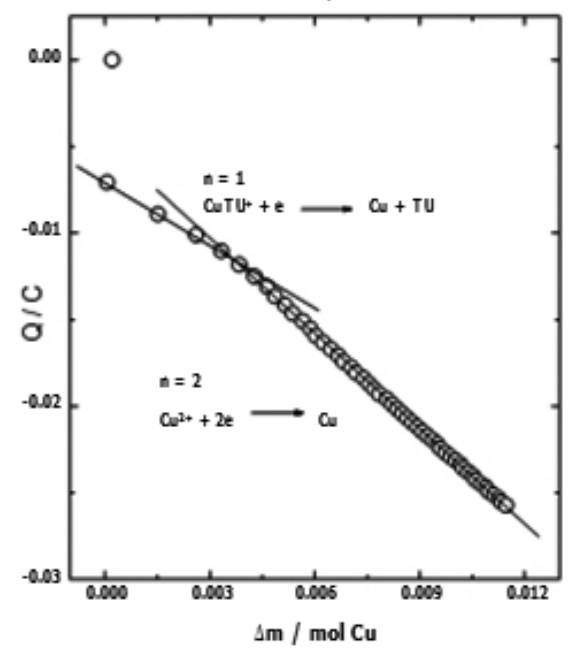

Fig.11. Charge-mass-time relationship corresponding to the EQCM Au/ $\mathrm{Cu}_{\text {electrodeposited }} / \mathrm{H}_{2} \mathrm{SO}_{4} 0.3 \mathrm{~mol} \mathrm{~L}^{-1}, 50 \mathrm{~m} \mathrm{~mol} \mathrm{~L}-1 \mathrm{CuSO}_{4}, 1.4 \cdot 10^{-3} \mathrm{~mol} \mathrm{~L}^{-1} \mathrm{TU}$ interface. Scan rate $0.1 \mathrm{~V} \mathrm{~s}^{-1}$. The electrode was previously held at the open circuit potential $(-0.6 \mathrm{~V})$, during 10 seconds.

Figure 11a shows the evolution of the charge and $\Delta$ mass curves in the potential interval where only the copper electrodeposition takes place. From Figure $11 \mathrm{~b}$ is deduced the exchange of either 1 and 2 electrons in the electrochemical reactions related to the following redox couples :

$$
\begin{gathered}
\mathrm{CuTU}^{+}+\mathrm{e} \rightarrow \mathrm{Cu}+\mathrm{TU} \\
\mathrm{Cu} 2^{+}+2 \mathrm{e} \rightarrow \mathrm{Cu}
\end{gathered}
$$

According to these charge/mass relationships, the $\mathrm{Cu}(\mathrm{I})$ - TU redox couple should participate in the beginning of the copper electrodeposition process. Furthermore, as it appears nearby the open circuit potential, it behaves like a reversible system.

The ability of $\mathrm{TU}$ to form $\mathrm{Cu}(\mathrm{I})$ complexes that depolarizes the copper electrodeposition reaction could be the reason behind its wide use as a leveling agent in copper refineries. Because relatively high $\mathrm{TU}$ concentrations produces an increase in FDS, resulting in the blocking of the active sites at the electrode surface, the appropiate monitoring of the concentration of this additive in the tanks of industrial copper refineries deserves to be considered as an important factor for obtaining copper cathodes with an adequate morphology. 


\section{CONCLUSIONS}

Cyclic voltammetry and EQCM experiments showed that in acid solutions onto gold and copper electrodes TU is irreversibly electroadsorbed as FDS which remains at the surface blocking active sites. Current diminution and a shift in the potential of the electrochemical processes involved in the absence of TU in these electrodes were observed. A mass loss, attributed to the exit of hydronium ions and water molecules from the adsorbed species was observed during the electroadsorption process. On the other hand, the $\Delta$ m vs E profile related to theelectrochemical formation of the $\mathrm{Cu}(\mathrm{I})-\mathrm{TU}_{\mathrm{ads}}$ presented a loss of mass attributed to the exit of TU from the electrode surface.

The formation of $\mathrm{Cu}(\mathrm{I})$-TU and FDS was confirmed in the bulk of copper sulfate acid solutions. Actually, themass changes associated to TU/ FDS were not significant enough to prevent the copper electrodeposition process. However, the addition of TU produces a change in the mass response because $\mathrm{Cu}(\mathrm{I})-\mathrm{TU}$ is electroreduced to copper in the initial stages of the nucleation. Afterwards, as was observed in the charge-mass transient, the growth of the phase would be ruled by the electroreduction of $\mathrm{Cu}$ (II) to $\mathrm{Cu}(0)$.

\section{ACKNOWLEDEGEMENTS}

This work has been supported by FONDEF (Chile), project D03I1148.

\section{REFERENCES}

1. A.E. Bolzán, I.B. Wakenge, R.C. Salvarezza, A.J. Arvia, J. Electroanal. Chem, 475, 181. (1999)

2. A. Lukomska, S. Smolinski, J. Sobkowski, Electrochim. Acta, 46, 3111. (2001)

3. M. Alodan, W. Smyrl, Electrochim. Acta, 44, 299. (1998)

4. V. San Martín, S. Sanllorente, S. Palmero, Electrochim. Acta, 44, 579. (1998)
5. G.M. Brown, G.A. Hope, D.P.Schweinsberg, P.M. Fredericks, J. Electroanal. Chem, 380, 161. (1995)

6. G.M. Brown, G.A. Hope, J. Electroanal. Chem, 413, 153. (1996)

7. A. Vicenzo, P.L. Cavallotti, J. Appl. Electrochem. 32, 743. (2002)

8. P. Schilardi, S. Méndez, R. C. Salvarezza, and A. J. Arvia, Langmuir, 14, 2515. (1998)

9. C.M. Juarez and A.J. B. Dutra. Minerals Engineering, 13, 1083. (2000)

10. Z.D. Stankovic and M. Vukovic Electrochim. Acta, 41,) 2529. (1996)

11. H.G. Zhang, J.A.Doyle, C.C. Kenna, S.R. La Brooy, G.T. Hefter and I.M. Ritchie. Electrochim. Acta, 41. 389. (1996)

12. A.E. Bolzán, P.L. Schilardi, R.C.V. Piatti, T. Iwasita, A. Cuesta, C. Gutiérrez, A.J. Arvía. J. Electroanal Chem, 571, 59. (2004)

13. B. Reents, W. Plieth, V.A. MAcagno, G. I. Lacconi. J. Electroanal. Chem. 453, 121. (1998)

14. M. Szklarczyk, N. Nhu Hoa, P. Zelenay. J. Electroanal. Chem. 405, 111. (1996)

15. A.E. Bolzán, T. Iwasita, A.J. Arvia, J. Electroanal.Chem. 554-555, 49. (2003)

16. G. García, V. A. Macagno, G. I. Lacconi. Electrochim. Acta, 48, 1273. (2003)

17. A.E. Bolzán, P.L. Schilardi, R.C.V. Piatti, T. Iwasita, A. Cuesta, C. Gutierrez, A.J. Arvia, J. Electroanal.Chem. 571, 59. (2004)

18. A.E. Bolzán, R.C.V. Piatti, A.J. Arvia, J. Electroanal.Chem. 552, 19. (2003)

19. M. Yan, K. Liu, Z. Jiang, J. Electroanal.Chem. 408, 225. (1996)

20. I. Lukovits, I. Bakó, A. Shaban, E. Kálmán, Electrochim. Acta, 43, 131. (1998)

21. G. García, J. L. Rodríguez, G. I. Lacconi, E. Pastor, Langmuir, 20, 8773. (2004)

22. M. Tian, B.E. Conway, J. Appl. Electrochem. 34,) 533. (2004

23. A. Fanigliulo, C. Mele, B. Bozzini, Transactions of the Institute of Metal Finishing, 81, 75. (2003). 